\title{
Tahap berpikir geometri siswa SMP berdasarkan teori van Hiele ditinjau dari keterampilan geometri
}

\author{
Sdyoko Susanto ${ }^{1, \text { a, }}$, Ali Mahmudi ${ }^{2, \text { b }}$ \\ ${ }^{1}$ SMP Negeri 2 Antang Kalang \\ Jl. Desa Batu Agung, Antang Kalang, Kotawaringin Timur, Kalimantan Tengah 74356, Indonesia \\ ${ }^{2}$ Jurusan Pendidikan Matematika, Universitas Negeri Yogyakarta \\ Jl. Colombo No. 1, Karangmalang, Yogyakarta 55821, Indonesia \\ E-mail: ${ }^{\mathrm{a}}$ susantosdyoko@ gmail.com, ${ }^{\mathrm{b}}$ alimahmudi@uny.ac.id \\ * Corresponding Author
}

\section{ARTICLE INFO}

Article history

Received: 24 Nov. 2017

Revised: 10 Sept. 2021

Accepted: 11 Sept. 2021

\section{Keywords}

berpikir geometri, teori van

Hiele, keterampilan

geometri, geometric

thinking, van Hiele's theory,

geometry skill

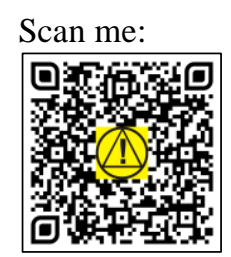

\section{ABSTRACT}

Penelitian ini bertujuan untuk mendeskripsikan tahap berpikir geometri siswa SMP menurut teori van Hiele ditinjau dari keterampilan geometri. Jenis penelitian adalah deskriptif menggunakan pendekatan kualitatif. Sampel penelitian adalah sembilan siswa kelas VIII dari tiga SMP Negeri Kota Sampit yang dipilih menggunakan teknik stratified proportional random sampling dan dilanjutkan dengan purposive sampling. Data penelitian dikumpulkan melalui wawancara mendalam terhadap subyek setelah diberikan tes keterampilan geometri. Teknik analisis data yang digunakan adalah kualitatif secara interaktif maju berkelanjutan di antara pengumpulan data, reduksi data, penyajian data, triangulasi data, dan penarikan kesimpulan. Hasil penelitian mengungkapkan bahwa: (1) keterampilan geometri siswa beragam pada tiap tahap berpikir geometri; (2) keterampilan verbal dan keterampilan menggambar merupakan keterampilan yang banyak dikuasai subjek; (3) keterampilan verbal merupakan keterampilan yang paling sulit bagi siswa; (4) tahap berpikir geometri siswa SMP kelas VIII SMP Negeri Sampit adalah 43,6\% siswa berada di tahap 0 (visualisasi), 35,1\% siswa di tahap 1 (analisis), dan 21,3\% siswa di tahap 2 (deduksi informal).

This study aimed to describe the geometric thinking stages of junior high school students according to van Hiele's theory in terms of geometry skills. This type of research is descriptive using a qualitative approach. The research sample was nine 8th grade students from three public junior high schools in Sampit City, Indonesia, who were selected using a stratified proportional random sampling technique and followed by purposive sampling. Research data were collected through in-depth interviews with subjects after being given a geometry skills test. The data analysis technique was an interactively qualitative, continuous process between data collection, data reduction, data presentation, data triangulation, and concluding. The results of the study revealed that: (1) students' geometry skills varied at each stage of geometric thinking; (2) verbal and drawing were the skills that mastered mainly by subjects; (3) verbal skill was the most difficult for students; (4) the geometric thinking stage of students was $43.6 \%$ of students in stage 0 (visualization), $35.1 \%$ of students in stage 1 (analysis), and $21.3 \%$ of students in stage 2 (informal deduction).

This is an open access article under the CC-BY-SA license.

How to Cite: Susanto, S., \& Mahmudi, A. (2021). Tahap berpikir geometri siswa SMP berdasarkan teori van Hiele ditinjau dari keterampilan geometri. Jurnal Riset Pendidikan Matematika, 8(1), 106-116. https://doi.org/10.21831/jrpm.v8i1.17044

\section{PENDAHULUAN}

Matematika merupakan bagian dari ilmu pengetahuan yang sangat penting bagi kehidupan manusia. Matematika merupakan salah satu ilmu dasar bagi ilmu-ilmu lain. Matematika ilmu yang kaya 
akan ide-ide dimana ide tersebut dapat digunakan sebagai penghubung ide antar ilmu guna menunjang perkembangan ilmu pengetahuan. Sebagaimana pendapat Chambers $(2008$, p. 9) bahwa matematika merupakan studi tentang pola-pola, hubungan dan kaya akan berbagai macam ide-ide yang saling terkait. Salah satu cabang dari matematika adalah geometri.

Menurut Gunham (2014, p. 3) geometri adalah cabang penting dari matematika maka dimungkinkan bagi orang untuk memahami dunia dengan membandingkan bentuk, obyek serta hubungannya. Adapun menurut Chambers (2008, p. 187) geometri merupakan kajian dalam matematika yang memiliki potensi besar untuk menjadikan suatu kajian menjadi lebih hidup. Untuk itu geometri sangat perlu untuk dipelajari. Menurut van de Walle (2001, p. 309) alasan perlunya mempelajari geometri di antaranya: "(a) geometry can provide a more complete appreciation of the word; (b) geometric explorations can develop problem-solving skills; (c) geometry play a key role in the study of other areas of mathematics; (d) geometry is use daily by many people; (e) geometry is enjoyable".

Perlunya mempelajari geometri juga dinyatakan Usiskin (1987, p. 26) yaitu: "(1) geometry as the study of visualization, drawing, and construction of figure, (2) geometry as study of the real, physical word, (3) geometry as a vehicle for representing mathematical or other concepts whose origin is not visual or physical, and (4) geometry as example of a mathematical system". Pernyataan tersebut bermakna bahwa geometri dipelajari melalui pola-pola visual. Cabang matematika yang menghubungkan matematika dengan dunia fisik atau dunia nyata, geometri juga dapat digunakan untuk menyajikan fenomena yang menghubungkan matematika atau konsep lain dengan fenomena yang tidak tampak atau tidak bersifat fisik, contoh sistem matematika. Dari apa yang telah dikemukakan, tampak sangat logis bahwa peranan geometri di jajaran matematika sangatlah kuat. Bukan hanya geometri mampu membina proses berpikir kritis siswa, tetapi juga sangat mendukung banyak topik lain dalam matematika. Ozerem (2012, p. 25) mengemukakan bahwa mempelajari geometri merupakan komponen penting dari pembelajaran matematika, karena memungkinkan peserta didik menganalisis dan menafsirkan dunia mereka tinggal serta melengkapinya dengan alat yang dapat diterapkan dalam bidang selain matematika.

Pada dasarnya geometri mempunyai peluang yang lebih besar untuk dipahami peserta didik dibandingkan cabang matematika lain, karena ide-ide geometri sudah dikenal oleh peserta didik sejak sebelum mereka masuk sekolah. Menurut Permendikbud nomor 58 tahun 2014 tentang Kurikulum 2013 SMP/ MTs, materi geometri mendapatkan proporsi relatif banyak (Kemendikbud, 2014). Materi yang dipelajari siswa SMP antara lain hubungan antar garis, sudut (membagi sudut dan melukis sudut), segitiga dan segiempat (unsur-unsur, sifat-sifat, luas serta keliling), dalil Pythagoras, lingkaran (garis singgung sekutu, lingkaran luar dan lingkaran dalam segitiga, dan melukisnya), bangun ruang sisi datar (kubus, balok, prisma, limas), kesebangunan dan kekongruenan, serta bangun ruang sisi lengkung (tabung, kerucut, bola serta menggunakannya dalam pemecahan masalah). Jika dipersentase pada tingkat SMP setidaknya ada 38,8\% materi pelajaran matematika berupa geometri. Proporsi yang begitu banyak diharapkan nantinya prestasi belajar geometri siswa akan lebih baik.

Geometri merupakan materi yang unik, hal ini karena dalam geometri selain siswa harus menguasai konsep siswa juga harus menguasai keterampilan geometri. Konsep dan keterampilan geometri saling terkait satu sama lain. Sehingga harapan dengan adanya proporsi yang banyak dalam mempelajari geometri nantinya siswa mampu menguasai konsep geometri dan menerapkan keterampilan geometri yang dimiliki seperti memvisualisasi, mengenal bermacam-macam bangun datar dan ruang, mendeskripsikan gambar, mensketsa gambar bangun, melabeli titik tertentu, dan kemampuan untuk mengenal perbedaan dan kesamaan antar bangun geometri. Banyaknya proporsi materi geometri dalam kurikulum matematika Indonesia tidak serta membuat prestasi belajar geometri juga meningkat. Justru menurut beberapa data penelitian baik dalam skala internasional maupun nasional menunjukkan bahwa prestasi belajar geometri belum optimal. Pada tingkat internasional menurut hasil penelitian yang diselenggarakan Trends in International Mathematics and Science Study (TIMSS) tahun 2011 menunjukkan ratarata prestasi matematika yang di raih siswa SMP Indonesia mengalami penurunan jika dibandingkan tahun 2007, dimana prestasi matematika tahun 2007 adalah 397 menjadi 386 pada tahun 2011 (Mullis et al., 2008, p. 35; Mullis et al., 2012, p. 42). Pada tahun 2007 peringkat Indonesia 36 dari 49 negara menjadi peringkat 38 pada tahun 2011 dari 42 negara. Rata-rata prestasi matematika Indonesia berada di bawah negara-negara ASEAN seperti, Singapura, Malaysia dan Thailand. Hasil penelitian dari TIMMS tersebut menunjukkan prestasi matematika siswa Indonesia masih perlu untuk ditingkatkan.

Selain prestasi matematika secara umum jika dilihat dari prestasi matematika pada topik geometri berdasarkan data TIMMS 2007 dan 2011 mengalami penurunan (Mullis et al., 2012, pp. 156-157). 
Selain geometri prestasi belajar siswa dalam menyelesaikan masalah bilangan, aljabar, serta statistik dan peluang juga mengalami penurunan serta berada di bawah rata-rata internasional sebagaimana terlihat pada Tabel 1.

Tabel 1. Rata-rata prestasi belajar matematika Indonesia

\begin{tabular}{ccccc}
\hline Tahun & Bilangan & Aljabar & Geometri & Statistik \& Peluang \\
\hline 2007 & 393 & 399 & 387 & 382 \\
2011 & 375 & 392 & 377 & 376 \\
Rata-rata & 500 & 500 & 500 & 500 \\
\hline
\end{tabular}

Selain penurunan prestasi belajar matematika di tingkat internasional, penurunan serupa juga terjadi pada tingkat nasional hal ini terlihat pada daya serap Ujian Nasional (UN). Prestasi materi geometri ditingkat nasional berdasar hasil UN tahun 2014 hingga 2016 mengalami penurunan. Hal yang sama juga terjadi pada di daerah Kabupaten Kotawaringin Timur yang berada pada Provinsi Kalimantan Tengah sebagaimana terlihat pada Tabel 2.

Tabel 2. Daya serap penguasaan materi geometri Kabupaten Kotawaringin Timur

\begin{tabular}{cccc}
\hline \multirow{2}{*}{ Tahun } & \multicolumn{3}{c}{ Geometri $(\%)$} \\
\cline { 2 - 4 } & Nasional & Provinsi & Kabupaten \\
\hline 2014 & 63,53 & 60,17 & 60,58 \\
2015 & 52,04 & 48,27 & 46,16 \\
2016 & 47,19 & 47,62 & 41,65 \\
\hline
\end{tabular}

Sumber: BSNP $(2014 ; 2015 ; 2016)$

Berdasarkan Tabel 2 dapat diketahui bahwa daya serap kemampuan siswa pada materi geometri secara berturut-turut adalah 60,58\%, 46,16\%, dan 41,65\%. Salah satu standar kompetensi materi geometri khususnya bangun ruang yang banyak dirasa sulit oleh kebanyakan siswa adalah memahami sifat-sifat kubus, balok, prisma, dan limas serta menentukan ukurannya. Hal ini didukung oleh data daya serap UN 2016, daya serap indikator diberikan gambar prisma dengan alas trapesium sebagai bidang frontal, peserta didik dapat menghitung luasnya jika unsur- unsur yang diperlukan diketahui adalah $38,55 \%$, dengan daya serap nasional $44,04 \%$. Ada juga data daya serap indikator menyelesaikan soal cerita yang berkaitan konsep kerangka pada balok adalah $37,79 \%$, dengan daya serap nasional 46,20\%.

Prestasi belajar geometri yang kurang memuaskan di tingkat internasional maupun nasional dapat disebabkan karena pembelajaran geometri belum optimal. Tentunya kurang optimalnya pembelajaran akan berdampak langsung dengan prestasi belajar geometri siswa. Kurang optimalnya dalam pembelajaran geometri ini tidak hanya disebabkan dari faktor guru ataupun siswa saja, setidaknya ada beberapa faktor yang mempengaruhi kurang optimalnya pembelajaran geometri, antara lain: (1) siswa masih menganggap bahwa geometri merupakan pelajaran yang sulit (Adolphus, 2011; Kurniasari, 2013; Wahyuni \& Rudhito, 2012); (2) pembelajaran tidak mengarah pada pemahaman (Wahyuni \& Rudhito, 2012); (3) metode pembelajaran kurang sesuai dengan karakteristik geometri siswa (Safrina et al., 2014); (4) guru sebagai sumber utama, dan siswa pasif (Yuniarti, 2011); (5) siswa cenderung suka menghafal dan tidak memahami konsep geometri (Aydog`du, 2014; Sarjiman, 2006; Sholikhakh et al., 2012); dan (5) siswa kurang antusias dalam pembelajaran (Sari, 2016, p.112).

Kurang optimalnya pembelajaran geometri dapat mengakibatkan tidak tercapainya tujuan pembelajaran geometri. National Council of Teacher of Mathematics (NCTM) mengemukakan bahwa ketika belajar geometri seorang siswa harus memiliki beberapa kemampuan. Menurut NCTM (2000, p. 232) secara umum kemampuan geometri yang harus dimiliki siswa adalah: 1) mampu menganalisis karakter dan sifat dari bentuk geometri baik dua dimensi dan tiga dimensi serta mampu membangun argumenargumen matematika mengenai hubungan geometri dengan yang lainnya; 2) mampu menentukan kedudukan suatu titik dengan lebih spesifik dan gambaran hubungan spasial dengan sistem yang lain; 3) aplikasi transformasi dan menggunakannya secara simetris untuk menganalisis situasi matematika; dan 4) menggunakan visualisasi, penalaran spasial, dan model geometri untuk memecahkan permasalahan. Selain itu dalam belajar geometri siswa juga dituntut untuk memiliki keterampilan geometri, karena dengan keterampilan geometri akan membantu siswa dalam memahami konsep geometri dengan baik. Hoffer (1981, p. 11) mengemukakan ada lima keterampilan dasar dalam belajar geometri, yakni: 
keterampilan visual (visual skill), keterampilan verbal (descriptive skill), keterampilan menggambar (drawing skill), keterampilan logika (logical skill), dan keterampilan terapan (applied skill). Keterampilan-keterampilan tersebut berkaitan erat dengan proses pembelajaran geometri.

Belajar geometri memerlukan kemampuan konsep yang matang sehingga dengan konsep yang matang siswa nantinya mampu menerapkan keterampilan geometri. Selain itu dalam belajar geometri harus dilakukan secara bertahap dan disesuaikan dengan perkembangan karakteristik siswa. Salah satu teori belajar geometri yang banyak digunakan para ahli dalam mengajarkan geometri adalah teori van Hiele. Teori van Hiele merupakan hasil riset dari dua pasangan suami istri dari Belanda yaitu Pierre Marie van Hiele-Geldof dan Dina van Hiele. Secara khusus mereka menemukan teori tahap berpikir siswa dalam belajar geometri. Pierre Marie van Hiele-Geldof dan Dina van Hiele (Kennedy et al., 2008, p. 396) mengemukakan bahwa terdapat lima tahap berpikir yang harus dilalui siswa dalam memahami geometri, yaitu tahap 0 (visualisasi), tahap 1 (analisis), tahap 2 (deduksi informal), tahap 3 (deduksi), dan tahap 4 (rigor).Kelima tahapan ini sangat berkaitan erat dengan pembentukan konsep dalam geometri.

Penelitian tentang tahap berpikir geometri sudah banyak dilakukan di mana hasilnya menunjukkan bahwa tahap berpikir geometri siswa SMP berada pada tahap deduksi informal dan sebagian besar pada tahap visualisasi (Abdullah \& Zakaria, 2013; Burger \& Shaughnessy, 1986; Clements \& Battista, 1992; van de Walle, 2001). Selain mengenai tahap berpikir geometri, juga ada beberapa penelitian yang menunjukkan pentingnya mengetahui tahap berpikir geometri. Idris (2009, p. 105) menyimpulkan bahwa kesadaran dan pengetahuan tentang tahap berpikir geometri siswa berdasarkan teori van Hiele dapat digunakan sebagai aset yang bermanfaat bagi guru dalam mengajar geometri. Selain itu, Vojkuvkova dan Haviger (2015, p. 918) menunjukkan bahwa teori van Hiele dapat membantu dalam meningkatkan berpikir geometri siswa. Sedangkan Kurniawati et al. (2015, p. 106) dari hasil penelitiannya menyarankan bahwa karena siswa memiliki karakter berpikir geometri yang berbeda, maka untuk mengetahuinya diperlukan suatu tes/kuis tertentu. Berdasarkan uraian tersebut, maka tujuan dari penelitian ini adalah untuk mendeskripsikan tahap berpikir geometri siswa SMP menurut teori van Hiele ditinjau dari keterampilan geometri.

\section{METODE}

Penelitian ini merupakan penelitian deskriptif dengan pendekatan kualitatif. Penelitian ini dilakukan dengan menggunakan empat tahap. Tahap pertama berupa observasi terhadap pembelajaran dikelas. Observasi ini dilakukan guna melengkapi dan mendukung data hasil tes penempatan geometri, tes keterampilan geometri dan hasil wawancara mendalam keterampilan geometri siswa. Tahap kedua berupa tes penempatan geometri, tes berikan bertujuan untuk mengetahui dan menentukan letak tahapan berpikir geometri siswa menurut teori van Hiele. Tahap ketiga berupa pemberian tes keterampilan geometri. Tes ini digunakan untuk mengetahui tahap berpikir geometri siswa ditinjau dari keterampilan geometrinya. Tahap keempat berupa wawancara mendalam kepada subjek penelitian. Wawancara dilakukan guna menggali informasi mengenai keterampilan geometri siswa dari tiap tahap berpikir geometri menurut teori van Hiele.

Penelitian ini dilaksanakan di SMP Negeri 1 Sampit, SMP Negeri 3 Sampit, dan SMP Negeri 7 Sampit, Kabupaten Kotawaringin Timur, Provinsi Kalimantan Tengah. Subjek penelitian ini adalah 9 siswa di tiga SMP negeri Sampit. Penentuan subjek didahului dengan pengambilan sampel. Pengambilan sampel didahului dengan penentuan strata/tingkat sekolah. Penentuan strata menggunakan prosedur stratified proportional random sampling yakni penentuan sampel dengan memperhatikan stratastrata sekolah berdasarkan nilai UN SMP. Setelah dilakukan stratifikasi terpilihlah tiga sekolah yang mewakili setiap strata yaitu SMPN 1 Sampit (A/tinggi), SMPN 3 Sampit (B/sedang), dan SMPN 7 Sampit (C/rendah). Setelah sekolah yang mewakili masing-masing strata terpilih, tahap selanjutnya adalah memilih subjek penelitian. Penentuan subjek dengan menggunakan teknik purposive sampling, tetapi sebelumnya dari tiap sekolah terpilih yang mewakili strata diambil satu kelas perwakilan, yaitu kelas VIII-D SMPN 1dengan jumlah 36 siswa, kelas VIII-A SMPN 3 dengan jumlah 31 siswa, dan kelas VIII-A SMPN 7 berjumlah 24 siswa.

Setelah mendapatkan kelas pada tiap sekolah kemudian diberikan tes penempatan geometri guna mengetahui letak tahap berpikir geometri siswa. Setelah tahap berpikir geometri siswa diketahui, maka selanjutnya adalah mengambil 3 siswa dalam tiap tahap untuk diberi tes keterampilan geometri serta 
wawancara. Dalam pemilihan siswa yang mewakili tiap tahap berpikir geometri peneliti menggunakan teknik purposive sampling, dan terpilih 3 siswa dari sekolah A, 4 siswa dari sekolah B, dan 2 siswa dari sekolah C.

Teknik pengumpulan data yang digunakan dalam penelitian ini adalah tes, wawancara, dan observasi. Pada penelitian ini digunakan dua jenis tes yakni: (1) tes penempatan geometri berpikir van Hiele, dan (2) tes keterampilan geometri. Tes penempatan geometri digunakan untuk mengetahui tahap berpikir geometri siswa menurut van Hiele, banyak soal ada 4 butir yang disusun sesuai dengan kisi-kisi berdasarkan karakteristik tahapan berpikir van Hiele. Sedangkan tes keterampilan geometri digunakan untuk mengetahui kemampuan keterampilan geometri siswa pada tahapan berpikir geometri menurut van Hiele. Banyaknya soal adalah 3 butir yang disusun sesuai dengan kisi-kisi karakteristik keterampilan geometri berdasar tahapan berpikir van Hiele.

Pada penelitian ini analisis data dilakukan secara deskriptif kualitatif dengan memberikan narasi yang logis sesuai dengan kepentingan dari penelitian. Analisis ini dilakukan selama dan setelah pengumpulan data. Analisis data hasil observasi, tes penempatan geometri dan wawancara dilakukan selama pengumpulan data berlangsung. Sedangkan analisis hasil tes keterampilan geometri dilakukan setelah pengumpulan data. Langkah-langkah analisis data dilakukan dengan tahapan pengumpulan data, reduksi data, penyajian data, triangulasi data dan penarikan kesimpulan. Untuk memperoleh data yang valid langkah yang dilakukan peneliti antara lain: melakukan observasi proses pembelajaran, memberikan tes penempatan berpikir geometri van Hiele, memeriksa hasil tes penempatan berpikir geometri sesuai dengan rubrik penilaian, memberikan tes keterampilan geometri, dan melakukan wawancara mendalam terkait keterampilan geometri.

Setelah data penelitian diperoleh langkah selanjutnya adalah melakukan reduksi data di antaranya dengan mengoreksi hasil pekerjaan siswa yang masih berupa data mentah kemudian ditransformasikan pada catatan, menyederhanakan hasil wawancara menjadi susunan bahasa yang baik dan rapi kemudian ditransformasikan dalam catatan. Tahap selanjutnya adalah menyajikan data dengan menyampaikan informasi berdasarkan data yang dimiliki dan disusun secara baik dan runtut, sehingga mudah dilihat, dibaca, dan dipahami tentang suatu kejadian dan tindakan atau peristiwa dalam bentuk teks naratif. Tahap penyajian data yang dilakukan dalam penelitian ini antara lain: menyajikan data hasil pekerjaan siswa, dan menyajikan hasil wawancara yang telah direkam. Tahap terakhir setelah data di reduksi dan disajikan serta dianalisis adalah penarikan kesimpulan. Penarikan kesimpulan dalam penelitian ini menggunakan teknik triangulasi yakni menarik kesimpulan dengan membandingkan data hasil tes penempatan geometri, observasi, tes keterampilan geometri, dan wawancara untuk mengetahui keterampilan geometri siswa pada tahap berpikir geometri menurut van Hiele.

\section{HASIL DAN PEMBAHASAN}

\section{Hasil Penelitian}

Data yang diperoleh dalam penelitian ini adalah data tahapan berpikir geometri siswa dan data keterampilan geometri siswa berdasar tahap berpikir geometri. Berikut berturut-turut disajikan deskripsi data hasil penelitian.

Tabel 3. Distribusi tahap berpikir geometri siswa menurut teori van Hiele

\begin{tabular}{lccccc}
\hline Sekolah & Strata & Jumlah & Tahap 0 & Tahap 1 & Tahap 2 \\
\hline SMPN 1 & $\mathrm{A}$ & 36 & 11 & 13 & 12 \\
SMPN 3 & $\mathrm{B}$ & 31 & 10 & 13 & 8 \\
SMPN 7 & $\mathrm{C}$ & 27 & 20 & 7 & 0 \\
\hline Jumlah & & 94 & 41 & 33 & 20 \\
\hline Persentase & & & $43,6 \%$ & $35,1 \%$ & $21,3 \%$ \\
\hline
\end{tabular}

Keterangan: $\mathrm{A}=$ Tinggi, $\mathrm{B}=$ Sedang, $\mathrm{C}=$ Rendah

Berdasarkan Tabel 3 diperoleh informasi bahwa tahap berpikir geometri 2 (deduksi informal) terdapat $21,3 \%$, tahap 1 (analisis) $35,1 \%$ dan siswa yang berada pada tahap 0 (visualisasi) yakni sebesar 43,6\%. Pada sekolah strata tinggi/A tahap berpikir geometri siswa paling banyak berada pada tahap 1 (analisis) begitu pun juga pada sekolah strata sedang/B. sedangkan pada sekolah strata rendah/C siswa terbanyak pada tahap 0 (visualisasi). 

Tabel 4.

Selanjutnya hasil analisis keterampilan geometri tahap visualisasi secara rinci di sajikan pada

Tabel 4. Keterampilan geometri siswa di tahap visualisasi

\begin{tabular}{|c|c|c|c|c|c|c|c|c|c|c|c|c|c|c|c|}
\hline \multirow{3}{*}{ Subyek } & \multicolumn{15}{|c|}{ Keterampilan geometri } \\
\hline & \multicolumn{3}{|c|}{ Visual } & \multicolumn{3}{|c|}{ Verbal } & \multicolumn{3}{|c|}{ Gambar } & \multicolumn{3}{|c|}{ Logika } & \multicolumn{3}{|c|}{ Terapan } \\
\hline & 0 & 1 & 2 & 0 & 1 & 2 & 0 & 1 & 2 & 0 & 1 & 2 & 0 & 1 & 2 \\
\hline $\mathrm{SV}_{1}$ & $\sqrt{ }$ & $\sqrt{ }$ & $\sqrt{ }$ & $\sqrt{ }$ & $\sqrt{ }$ & - & $\sqrt{ }$ & $\sqrt{ }$ & $\sqrt{ }$ & $\sqrt{ }$ & $\sqrt{ }$ & $\sqrt{ }$ & $\sqrt{ }$ & $\sqrt{ }$ & $\sqrt{ }$ \\
\hline $\mathrm{SV}_{2}$ & $\sqrt{ }$ & $\sqrt{ }$ & - & - & - & - & $\sqrt{ }$ & - & $\sqrt{ }$ & $\sqrt{ }$ & - & - & $\sqrt{ }$ & - & - \\
\hline $\mathrm{SV}_{3}$ & $\sqrt{ }$ & $\sqrt{ }$ & $\sqrt{ }$ & $\sqrt{ }$ & $\sqrt{ }$ & - & $\sqrt{ }$ & $\sqrt{ }$ & $\sqrt{ }$ & $\sqrt{ }$ & - & - & $\sqrt{ }$ & - & - \\
\hline
\end{tabular}

Keterangan: $\mathrm{SV}_{1}=$ subjek visualisasi ke- $1, \mathrm{SV}_{2}=$ subjek visualisasi $\mathrm{ke}-2, \mathrm{SV}_{3}=$ subjek visualisasi $\mathrm{ke}-3$

Berdasarkan Tabel 4 dapat diketahui bahwa dari $\mathrm{SV}_{1}, \mathrm{SV}_{2}$, dan $\mathrm{SV}_{3}$ hanya $\mathrm{SV}_{2}$ yang belum menguasai salah satu keterampilan geometri tahap 0 (visualisasi). $\mathrm{SV}_{2}$ belum menguasai keterampilan verbal. $\mathrm{SV}_{1}$ memiliki keterampilan visual, menggambar, logika, dan terapan setara dengan indikator keterampilan geometri tahap 2 (deduksi informal). Kemampuan verbal Subjek $\mathrm{SV}_{1}$ setara dengan kemampuan keterampilan verbal tahap 1 (analisis). Sementara untuk $\mathrm{SV}_{3}$ keterampilan visual dan menggambar setara dengan kemampuan berpikir geometri siswa tahap 2 (deduksi informal).

Kemampuan $\mathrm{SV}_{2}$ secara umum jika dilihat dari keterampilan visual, menggambar, logika, dan terapan sudah memenuhi kriteria indikator keterampilan geometri tahap 0 (visualisasi). Untuk keterampilan visual $\mathrm{SV}_{2}$ kemampuannya setara dengan kemampuan keterampilan visual tahap 1 (analisis). Kemudian untuk keterampilan verbal keterampilan $\mathrm{SV}_{2}$ belum sesuai dengan indikator keterampilan verbal tahap 0 (visualisasi). Berdasarkan Tabel 4 keterampilan geometri $\mathrm{SV}_{3}$ secara keseluruhan sudah mencapai indikator keterampilan geometri tahap 0 (visualisasi). Keterampilan visual dan menggambar subjek $\mathrm{SV}_{3}$ setara dengan indikator keterampilan tahap 2 (deduksi informal). Untuk kemampuan keterampilan menggambar $\mathrm{SV}_{3}$ setara dengan indikator keterampilan menggambar tahap 1 (analisis). Sedangkan keterampilan logika dan terapan $\mathrm{SV}_{3}$ sesuai dengan indikator keterampilan logika dan terapan tahap 0 (visualisasi).

Selanjutnya hasil analisis keterampilan geometri siswa pada tahap analisis secara rinci di sajikan pada Tabel 5.

Tabel 5. Keterampilan geometri siswa di tahap analisis

\begin{tabular}{|c|c|c|c|c|c|c|c|c|c|c|c|c|c|c|c|}
\hline \multirow{3}{*}{ Subyek } & \multicolumn{15}{|c|}{ Keterampilan geometri } \\
\hline & \multicolumn{3}{|c|}{ Visual } & \multicolumn{3}{|c|}{ Verbal } & \multicolumn{3}{|c|}{ Gambar } & \multicolumn{3}{|c|}{ Logika } & \multicolumn{3}{|c|}{ Terapan } \\
\hline & 0 & 1 & 2 & 0 & 1 & 2 & 0 & 1 & 2 & 0 & 1 & 2 & 0 & 1 & 2 \\
\hline $\mathrm{SA}_{1}$ & $\sqrt{ }$ & $\sqrt{ }$ & $\sqrt{ }$ & $\sqrt{ }$ & $\sqrt{ }$ & - & $\sqrt{ }$ & $\sqrt{ }$ & $\sqrt{ }$ & $\sqrt{ }$ & $\sqrt{ }$ & - & $\sqrt{ }$ & $\sqrt{ }$ & $\sqrt{ }$ \\
\hline $\mathrm{SA}_{2}$ & $\sqrt{ }$ & $\sqrt{ }$ & $\sqrt{ }$ & $\sqrt{ }$ & - & - & $\sqrt{ }$ & - & $\sqrt{ }$ & $\sqrt{ }$ & - & $\sqrt{ }$ & $\sqrt{ }$ & $\sqrt{ }$ & $\sqrt{ }$ \\
\hline $\mathrm{SA}_{3}$ & $\sqrt{ }$ & $\sqrt{ }$ & $\sqrt{ }$ & $\sqrt{ }$ & - & $\sqrt{ }$ & $\sqrt{ }$ & $\sqrt{ }$ & $\sqrt{ }$ & $\sqrt{ }$ & $\sqrt{ }$ & - & $\sqrt{ }$ & - & - \\
\hline
\end{tabular}

Keterangan: $\mathrm{SA}_{1}=$ subjek analisis ke-1, $\mathrm{SA}_{2}=$ subjek analisis ke-2, $\mathrm{SA}_{3}=$ subjek analisis ke-3

Berdasarkan Tabel 5 dapat diketahui bahwa keterampilan geometri $\mathrm{SA}_{1}$ adalah: 1) keterampilan visual berada pada tahap 2 (deduksi informal), 2) keterampilan verbal berada pada tahap 1 (analisis), 3) keterampilan menggambar berada pada tahap (deduksi informal), 4) keterampilan logika berada pada tahap 1 (analisis), dan 5) keterampilan terapan berada pada tahap 2 (deduksi informal). Sehingga secara keseluruhan $\mathrm{SA}_{1}$ keterampilan geometri yang dimiliki sudah sesuai dengan indikator, bahkan untuk keterampilan visual, menggambar, dan terapan sudah berada pada tahap 2 (deduksi informal).

Untuk $\mathrm{SA}_{2}$ memiliki keterampilan geometri yaitu: 1) keterampilan visual berada pada tahap (deduksi informal), 2) keterampilan verbal berada pada tahap (visualisasi), 3) keterampilan menggambar berada pada tahap 0 (visualisasi), 4) keterampilan logika berada pada tahap 0 (visualisasi), dan 5) keterampilan terapan berada pada tahap 2 (deduksi informal). Tahapan berpikir geometri subyek $\mathrm{SA}_{2}$ berdasarkan indikator keterampilan geometri pada tahap 1 (analisis), maka hanya ada dua keterampilan yang baru dicapai, yakni ketrampilan visual dan terapan. Sedangkan untuk keterampilan verbal, menggambar, serta logika keterampilan $\mathrm{SA}_{2}$ masih berada pada tahap 0 (visualisasi). Sedangkan $\mathrm{SA}_{3}$ memiliki keterampilan geometri: 1) keterampilan visual berada pada tahap 2 (deduksi informal), 2) keterampilan verbal berada pada tahap 0 (visualisasi), 3) keterampilan menggambar berada pada tahap 2 (deduksi 
informal), 4) keterampilan logika berada pada tahap 1 (analisis), dan 5) Keterampilan terapan berada pada tahap 0 (visualisasi). Sehingga berdasarkan pencapaian $\mathrm{SA}_{3}$ maka ada dua keterampilan yang belum dapat dicapai, yakni keterampilan verbal dan terapan. Sedangkan untuk keterampilan visual, menggambar, serta logika $\mathrm{SA}_{3}$ sudah sesuai dengan indikator keterampilan geometri tahap 1 (analisis).

Selanjutnya hasil analisis keterampilan geometri tahap deduksi informal secara rinci disajikan pada Tabel 6. Berdasarkan Tabel 6 menunjukkan bahwa SDI secara umum keterampilan geometrinya adalah: 1). Keterampilan visual berada pada tahap 2 (deduksi informal), 2). Keterampilan verbal berada pada tahap 1 (analisis), 3). Keterampilan menggambar berada pada tahap 2 (deduksi informal), 4). Keterampilan logika berada pada tahap 2 (deduksi informal), dan 5). Keterampilan terapan berada pada tahap 2 (deduksi informal). Sehingga secara keseluruhan subjek SDI $\mathrm{S}_{1}$ memiliki keterampilan geometri sudah sesuai dengan indikator keterampilan geometri tahap 2 (deduksi informal), hanya pada keterampilan verbal saja yang masih pada tahap 1 (analisis).

Tabel 6. Keterampilan geometri siswa di tahap deduksi informal

\begin{tabular}{|c|c|c|c|c|c|c|c|c|c|c|c|c|c|c|c|}
\hline \multirow{3}{*}{ Subyek } & \multicolumn{15}{|c|}{ Keterampilan geometri } \\
\hline & \multicolumn{3}{|c|}{ Visual } & \multicolumn{3}{|c|}{ Verbal } & \multicolumn{3}{|c|}{ Gambar } & \multicolumn{3}{|c|}{ Logika } & \multicolumn{3}{|c|}{ Terapan } \\
\hline & 0 & 1 & 2 & 0 & 1 & 2 & 0 & 1 & 2 & 0 & 1 & 2 & 0 & 1 & 2 \\
\hline $\mathrm{SDI}_{1}$ & $\sqrt{ }$ & $\sqrt{ }$ & $\sqrt{ }$ & $\sqrt{ }$ & $\sqrt{ }$ & - & $\sqrt{ }$ & $\sqrt{ }$ & $\sqrt{ }$ & $\sqrt{ }$ & $\sqrt{ }$ & $\sqrt{ }$ & $\sqrt{ }$ & $\sqrt{ }$ & $\sqrt{ }$ \\
\hline $\mathrm{SDI}_{2}$ & $\sqrt{ }$ & $\sqrt{ }$ & $\sqrt{ }$ & $\sqrt{ }$ & $\sqrt{ }$ & - & $\sqrt{ }$ & $\sqrt{ }$ & $\sqrt{ }$ & $\sqrt{ }$ & $\sqrt{ }$ & - & $\sqrt{ }$ & $\sqrt{ }$ & - \\
\hline $\mathrm{SDI}_{3}$ & $\sqrt{ }$ & $\sqrt{ }$ & $\sqrt{ }$ & $\sqrt{ }$ & $\sqrt{ }$ & - & $\sqrt{ }$ & $\sqrt{ }$ & $\sqrt{ }$ & $\sqrt{ }$ & $\sqrt{ }$ & $\sqrt{ }$ & $\sqrt{ }$ & $\sqrt{ }$ & - \\
\hline
\end{tabular}

Keterangan: $\mathrm{SDI}_{1}=$ subjek deduksi informal ke-1, $\mathrm{SDI}_{2}=$ subjek deduksi informal ke-2, $\mathrm{SA}_{3}=$ subjek deduksi informal ke-3

Selanjutnya untuk $\mathrm{SDI}_{2}$ memiliki keterampilan geometri: 1). Keterampilan visual berada pada tahap 2 (deduksi informal), 2). Keterampilan verbal berada pada tahap 1 (analisis), 3). Keterampilan menggambar berada pada tahap 2 (deduksi informal), 4). Keterampilan logika berada pada tahap 1 (analisis), dan 5). Keterampilan terapan berada pada tahap 1 (analisis). Tahapan berpikir geometri $\mathrm{SDI}_{2}$ jika dilihat dari keterampilan geometri secara mayoritas berada pada tahap analisis dimana dari lima ketrampilan hanya ada dua keterampilan yang berada sesuai dengan tahap berpikir geometri subjek $\mathrm{SDI}_{2}$. Keterampilan geometri subyek yang berada pada tahap 2 (deduksi informal) adalah ketrampilan visual dan menggambar. Sedangkan untuk keterampilan verbal, logika, serta terapan yang dikuasai subjek $\mathrm{SDI}_{2}$ masih berada pada tahap 1 (analisis). Untuk $\mathrm{SDI}_{3}$ memiliki keterampilan geometri: 1). Keterampilan visual berada pada tahap 2 (deduksi informal), 2). Keterampilan verbal berada pada tahap 1 (analisis), 3). Keterampilan menggambar berada pada tahap (deduksi informal), 4). Keterampilan logika berada pada tahap 1 (analisis), dan 5). Keterampilan terapan berada pada tahap 1 (analisis). Tahapan berpikir geometri $\mathrm{SDI}_{3}$ jika dilihat dari keterampilan geometri, maka ada tiga keterampilan verbal, logika dan terapan subyek berada pada keterampilan geometri tahap 1 (analisis). Sedangkan jika dilihat dari keterampilan visual dan menggambar $\mathrm{SDI}_{3}$ berada pada tahap 2 (deduksi informal).

\section{Pembahasan}

Berdasarkan hasil penelitian dan indikator keterampilan berpikir geometri menunjukkan bahwa keterampilan geometri siswa untuk setiap tahap berpikir geometri sangat beragam. Siswa yang berada pada tahap 0 (visualisasi) menurut Tabel 4 memiliki keterampilan geometri yang beragam. Keterampilan berpikir geometri siswa tahap 0 (visualisasi) memiliki keterampilan geometri: keterampilan visual (visual skill), dapat mengelompokkan bangun berdasarkan hubungan di antara beberapa bentuk bangun. Keterampilan verbal (descriptive skill), dapat membentuk definisi dengan mendaftar semua sifat matematis bangun. Keterampilan menggambar (drawing skill), dapat mengkonstruksi bangun tertentu dengan diberikan bangun-bangun lain yang berkaitan. Keterampilan logika (logical skill), subjek $\mathrm{SV}_{1}$ dapat menyebutkan persamaan antar bangun berdasarkan sifat-sifatnya, subjek $\mathrm{SV}_{2}$, dan $\mathrm{SV}_{3}$ dapat menentukan persamaan dan perbedaan berdasarkan bentuknya. Keterampilan terapan (applied skill), subjek $\mathrm{SV}_{1}$ dapat memahami konsep model matematika yang memiliki hubungan antara sifat-sifat bangun, sedangkan subjek $\mathrm{SV}_{2}$ dan $\mathrm{SV}_{3}$ dapat menyebutkan benda-benda di sekelilingnya yang termasuk ke dalam jenis suatu bangun.

Tahap berpikir geometri siswa tahap 1 (analisis) memiliki keterampilan geometri: keterampilan visual (visual skill), dapat mengelompokkan bangun berdasarkan hubungannya. Ketrampilan verbal 
(descriptive skill) subjek $\mathrm{SA}_{1}$, dapat membentuk definisi dengan mendaftar semua sifat matematis bangun, subjek $\mathrm{SA}_{2}$ dan $\mathrm{SA}_{3}$ dapat membentuk definisi sederhana dari deskripsi fisik bangun. Keterampilan menggambar (drawing skill), dapat mengkonstruksi bangun tertentu dari bangun lain terkait. Keterampilan logika (logical skill) subyek $\mathrm{SA}_{1}$ dan $\mathrm{SA}_{3}$, dapat menyebutkan persamaan dan perbedaan bangun berdasarkan sifat-sifatnya, sedangkan subjek $\mathrm{SA}_{2}$ dapat menyebutkan persamaan antar bangun berdasarkan sifatnya. Keterampilan terapan (applied skill), subjek $\mathrm{SA}_{1}$ dan $\mathrm{SA}_{2}$ dapat memahami konsep model matematika yang memiliki hubungan antara sifat-sifat bangun, subjek STA ${ }_{3}$ dapat menyebutkan benda-benda di sekelilingnya yang termasuk ke dalam jenis suatu bangun.

Tahap berpikir geometri siswa di tahap 2 (deduksi informal) memiliki keterampilan geometri: keterampilan visual (visual skill), dapat mengelompokkan bangun berdasarkan hubungannya. Keterampilan verbal (descriptive skill), dapat membentuk definisi dengan mendaftar semua sifat matematis bangun. Keterampilan menggambar (drawing skill), dapat mengkonstruksi bangun tertentu dengan diberikan bangun-bangun lain yang berkaitan. Keterampilan logika (logical skill), dapat menyebutkan persamaan antar bangun berdasarkan sifat-sifat dan dapat menentukan apakah sifat suatu bangun tersebut juga dimiliki bangun lain. Keterampilan terapan (applied skill) subyek $\mathrm{SDI}_{1}$ dapat memahami konsep model matematika yang memiliki hubungan antara sifat-sifat bangun. Sedangkan subyek $\mathrm{SDI}_{2}$, dan $\mathrm{SDI}_{3}$ dapat menjelaskan sifat-sifat geometris dari benda-benda di sekitarnya dan dapat menggunakan sifat-sifat geometri dalam kehidupan sehari-hari.

Berdasarkan Tabel 6 menunjukkan bahwa siswa pada tahap deduksi informal masih kesulitan dalam menguasai keterampilan verbal. Hoffer (1981, p. 15) mengemukakan bahwa keterampilan verbal meliputi kemampuan siswa untuk memberi nama yang tepat pada bangun yang diketahui, mengartikan kalimat yang mendeskripsikan bangun, mendeskripsikan secara akurat bermacam-macam sifat bangun, mendefinisikan bangun secara akurat dan singkat, merumuskan kalimat yang menunjukkan hubungan antara bangun-bangun, memahami perbedaan di antara definisi, postulat, dan teorema, mengenali yang diketahui dan diperlukan untuk menyelesaikan masalah, merumuskan perluasan hasil yang diketahui serta mendeskripsikan berbagai sistem deduktif.

Keterampilan verbal (descriptive skill) yang dikuasai subjek pada tahap 2 (deduksi informal) baru pada taraf membuat definisi dengan mendaftar semua sifat matematis. Hal ini menunjukkan bahwa kemampuan keterampilan verbal subyek berada pada tahap analisis, artinya bahwa subyek belum mampu untuk membuat definisi dari hubungan bangun yang salin terkait. Keterampilan verbal adalah kemampuan untuk mengungkapkan hubungan bangun datar, menunjukkan bangun datar menurut namanya, memvisualisasikan bangun datar menurut deskripsi verbal, mengungkapkan sifat-sifat bangun datar, dan merumuskannya. Misalnya membuat definisi kubus dari balok atau membuat definisi balok dari prisma atau membuat definisi kubus dari rhomboeder. Kesulitan dalam membuat definisi sebenarnya juga dialami oleh siswa pada tahap 1 (analisis) dari tiga subjek hanya $\mathrm{SA}_{1}$ yang mampu membuat definisi dengan menyebutkan sifat matematis dari bangun sedangkan subjek yang lain baru mampu membuat definisi dengan melihat bentuknya. Hal ini menunjukkan bahwa dari kelima keterampilan geometri, keterampilan verbal yang dirasa paling sulit sedangkan keterampilan visual dan menggambar dapat dikuasai dengan baik oleh semua siswa.

Keterampilan visual (visual skill) dan keterampilan menggambar (drawing skill) ini terkait tentang bagaimana siswa mampu memberikan nama suatu bangun berdasarkan bentuknya dan bagaimana siswa mampu dalam mengkontruksi suatu bangun jika diberikan bangun yang berkaitan. Hoffer (1981, p. 15) menyatakan bahwa keterampilan menggambar meliputi kemampuan siswa untuk membuat sketsa bangun dan memberi label secara akurat, menerjemahkan informasi verbal yang diketahui menjadi sebuah bangun, menggunakan sifat-sifat yang diketahui untuk menggambar bangun, bangun-bangun tertentu yang diketahui dapat digunakan untuk menggambar bangun-bangun lain yang berhubungan dengan bangun yang diketahui, mengenali kapan dan bagaimana menggunakan unsur-unsur pelengkap pada gambar, menarik kesimpulan dari informasi yang diberikan bagaimana menggambar bangun yang spesifik, memahami keterbatasan dan kemampuan alat-alat menggambar yang beragam, serta menggambarkan konsep yang tidak standar pada sistem deduktif.

Secara umum siswa yang berada pada tahap 0 (visualisasi), tahap 1 (analisis), dan tahap 2 (deduksi informal) mampu menguasai keterampilan menggambar dengan baik. Mereka dapat membuat gambar bangun secara akurat, menerjemahkan informasi verbal yang diberikan ke dalam gambar dengan menggunakan sifat-sifat yang diberikan, dan dapat mengkonstruksi bangun tertentu dengan diberikan bangunbangun lain yang berkaitan. Keterampilan visual dan menggambar ini selain dikuasai dengan baik oleh 
siswa pada semua tahap juga dikuasai dengan baik dari siswa yang berasal dari semua strata sekolah. Secara keseluruhan siswa yang berasal dari sekolah strata lebih baik memiliki keterampilan geometri lebih baik. Subjek yang berasal dari sekolah berstrata A (tinggi) keterampilan geometrinya lebih baik dibanding dengan subyek dari sekolah strata B (sedang) dan subyek dari sekolah strata B keterampilan geometrinya lebih baik dibanding dengan subyek dari sekolah strata C (rendah).

\section{SIMPULAN}

Penelitian ini menyimpulkan beberapa hal. Pertama, tahap berpikir geometri siswa SMP kelas VIII SMP Negeri Sampit adalah 43,6\% siswa berada di tahap 0 (visualisasi); 35,1\% siswa di tahap 1 (analisis), dan 21,3\% siswa ditahap 2 (deduksi informal). Kedua, tahap berpikir geometri siswa baik pada tahap visualisasi, analisis, maupun deduksi informal memiliki keterampilan geometri yang beragam. Ketiga, subjek yang berasal dari sekolah strata tinggi keterampilan geometrinya lebih baik dibanding dengan subjek dari sekolah strata sedang dan subjek dari sekolah strata keterampilan geometrinya lebih baik dibanding dengan subyek dari sekolah strata rendah. Keempat, keterampilan visual (visual skill) dan keterampilan menggambar (drawing skill) dapat dikuasai dengan baik oleh semua subjek. Sedangkan keterampilan verbal (descriptive skill) adalah keterampilan geometri yang susah untuk dikuasai subyek di semua tahapan berpikir geometri. Berdasarkan kesimpulan yang telah diperoleh disarankan agar guru dapat merancang pembelajaran matematika yang mampu memfasilitasi siswa untuk menghubungkan berbagai konsep geometri. Selain itu, guru matematika juga diharapkan melakukan pengembangan perangkat pembelajaran geometri berdasarkan tahap berpikir geometri menurut teori van Hiele. Peneliti lain juga diharapkan dapat menindaklanjuti temuan penelitian ini dengan melakukan penelitian lanjutan terkait intervensi yang tepat untuk meningkatkan kemampuan geometri siswa.

\section{DAFTAR PUSTAKA}

Abdullah, A. H., \& Zakaria, E. (2013). Enhancing students of geometric thinking through van Hiele's phase-based learning. Indian Journal of Science and Technology, 6(5), 4432-4446. https://dx.doi.org/10.17485/ijst/2013/v6i5.13

Adolphus, T. (2011). Problem of teaching and learning of geometry in secondary schools in rivers state, Nigeria. International Journal of Emerging Science, 1(2), 143-152.

Aydog`du, M. Z. (2014). A research on geometry problem solving strategies used by elementary mathematics teacher candidates. Journal of Educational and Instructional Studies in The World, 4(1), 53-62.

BSNP (Badan Standar Nasional Pendidikan). (2014). Laporan hasil UN SMP/MTs tahun pelajaran 2013/2014. BSNP.

BSNP (Badan Standar Nasional Pendidikan). (2015). Laporan hasil UN SMP/MTs tahun pelajaran 2014/2015. BSNP.

BSNP (Badan Standar Nasional Pendidikan). (2016). Laporan hasil UN SMP/MTs tahun pelajaran 2015/2016. BSNP.

Burger, W. F., \& Shaughnessy, J. M. (1986). Characterizing the van Hiele levels of development in geometry. Journal for Research in Mathematics Educations, 17(1), 31-48. https://doi.org/10.2307/749317

Chambers, P. (2008). Teaching mathematic: Developing as a reflective secondary teacher. Sage.

Clements, D. H., \& Battista, J. M. (1992). Geometry and spatial reasoning. In D. A. Grouws (Ed.), hanbdbook of reseach on mathematics teacing and learning (pp. 420-464) MacMillan.

Gunham, B. C. (2014). A case study on the investigation of reasoning skill in geometry. South African Journal of Educatioon, 34(2), 1-19. https://doi.org/10.15700/201412071156

Hoffer, A. (1981). Geometry is more than proof. The Mathematics Teacher, 74(1), 11-14. https://doi.org/10.5951/MT.74.1.0011 
Idris, N. (2009). The impact of using geometrys' skatchpad on Malaysian students' achievement and van Hiele geometric thinking. Journal of Mathematics Education, 2(2), 94-107. https://educationforatoz.com/images/_9734_8_Noraini.pdf

Kemendikbud. (2014). Peraturan Menteri Pendidikan dan Kebudayaan nomor 58 tahun 2014 tentang Kurikulum 2013 SMP/MTs. https://jdih.kemdikbud.go.id/arsip/Permendikbud\%20Nomor\%2058\%20Tahun\%202014digabungkan.pdf

Kennedy, L. M., Tipps, S., \& Jhonson, A. (2008). Guiding children's learning of mathematics (11th ed.). Thomson Higher Educations.

Kurniasari, I. (2013). Identifikasi kesalahan siswa dalam menyelesaiakn soal geometri materi dimensi tiga kelas XI IPA SMA. Seminar Nasional Matematika dan Pendidikan Matematika FMIPA UNY. Yogyakarta. https://eprints.uny.ac.id/10764/1/P\%20-\%2041.pdf

Kurniawati, M., Junaedi, I., \& Mariani, S. (2015). Analisis karakteristik berpikir geometri dan kemandirian belajar dalam pembelajaran fase van Hiele berbantuan Geometers Sketchpad. Unnes Journal of Mathematics Education Research, 4(2), 102-107. https://journal.unnes.ac.id/sju/index.php/ujmer/article/view/9836

Mullis, I. V. S., Martin, M. O., \& Foy, P. (2008). TIMSS 2007 international result in mathematics reports. TIMSS \& PIRLS International Study Center. https://timss.bc.edu/timss2007/mathreport.html

Mullis, I. V. S., Martin, M. O., \& Foy, P. (2012). TIMSS 2011 international result in mathematics reports. TIMSS \& PIRLS International Study Center.

https://timssandpirls.bc.edu/timss2011/international-results-mathematics.html

NCTM. (2000). Principle and standards for school mathematics. National Council of Teachers of Mathematics.

Ozerem, A. (2012). Misconceptions in geometry and suggested solutions for seventh grade students. Procedia - Social and Behavioral Sciences, 55, 720-729 https://doi.org/10.1016/j.sbspro.2012.09.557

Safrina, K., Ikhsan, M., \& Ahmad, A. (2014). Peningkatan kemampuan pemecahan masalah geometri melalui pembelajaran kooperatif berbasis teori van Hiele. Jurnal Didaktik Matematika, 1(1), 920. http://www.jurnal.unsyiah.ac.id/DM/article/view/1333

Sari, W. R. (2016). Pengembangan perangkat pembelajaran bangun ruang di SMP dengan pendekatan pendidikan matematika realistik. Jurnal Riset Pendidikan Matematika, 3(1),109-121. https://doi.org/10.21831/jrpm.v3i1.10407

Sarjiman, P. (2006). Peningkatan pemahaman rumus geometri melalui penedekatan realistik di sekolah dasar. Cakrawala Pendidikan, 25(1), 73-92. https://doi.org/10.21831/cp.v0i1.393

Sholikhakh, R., Rismono, R., \& Waluya, S. (2012). Pengembangan perangkat pembelajaran beracuan konstruktivisme dalam kemasan CD interaktif kelas VIII materi geometri dan pengukuran. Unnes Journal of Mathematics Education Research, 1(1), 13-19. https://journal.unnes.ac.id/sju/index.php/ujmer/article/view/19

Usiskin, Z. (1987). van Hiele levels of achievement in secondary school geometry: Final report of the cognitive development and achievement in secondary school geometry project. University of Chicago. https://files.eric.ed.gov/fulltext/ED220288.pdf

van de Walle, J. A. (2001). Elementary and middle school mathematics: teaching developmentally (4th ed.). Allyn and Bacon.

Vojkuvkova, I., \& Haviger, J. (2015). The van Hiele at Czech secondary school. Procedia-Social and Behavioral Sciences, 171, 912-918. https://doi.org/10.1016/j.sbspro.2015.01.209 
Wahyuni, A. T., \& Rudhito, M. A. (2012). Efektivitas pembelajaran dengan program Cabri 3D di bidang pembelajaran konvensional pada topik jarak garis dengan bidang. Prosiding Seminar Nasional Penelitian, Pendidikan dan Penerapan MIPA FMIPA UNY (pp. M1-M6). Yogyakarta. http://staffnew.uny.ac.id/upload/132326893/penelitian/1-makalah-pendidikan-matematika.pdf

Yuniarti, Y. (2011). Pendidikan matematika realistik indonesia (PMRI) untuk meningkatkan pemahaman konsep geometri di sekolah dasar. Eduhumaniora: Jurnal Pendidikan Dasar, 3(2), https://doi.org/10.17509/eh.v3i2.2809 